ABCD Arq Bras Cir Dig 2019;32(4):e1469

DOI: /10.1590/0102-672020180001e1469

\section{AUXILIARY THREAD TO TIE A SHORT THREAD OF A RUNNING SUTURE}

Fio auxiliar para atar fio curto em sutura contínua

\author{
Andy PETROIANU
}

Como citar este artigo: Petroianu A. Auxiliary thread to tie a short thread of a running suture. ABCD Arq Bras Cir Dig. 2019;32(4):e1469. DOl: /10.1590/0102-672020180001e1469

From the ${ }^{1}$ Faculdade de Medicina, Universidade Federal de Minas Gerais ('Medical School, Federal University of Minas Gerais), Belo Horizonte, MG, Brazil

\section{Correspondência:}

Andy Petroianu

E-mail: petroian@gmail.com

HEADINGS - Sutures. Suture techniques. Suture anchors.

DESCRITORES - Suturas. Técnicas de sutura. Âncoras de sutura.

Financial source: none

Conflict of interest: none

Received for publication: 28/02/2019

Accepted for publication: 15/08/2019

\section{INTRODUCTION}

W hen finishing a continuous suture, often a thread segment is too short to be tied. In this situation the knots are made with the aid of needle holders or hemostatic forceps, but the result may be unsatisfactory ${ }^{1,2,3}$. Another option is to fix it with another thread, which is tied with the short thread, increasing the cost of the operation.

The use of an auxiliary thread to facilitate the making the end knot of a continuous short-threaded suture has been used by the author for over 40 years with good results. It is likely that other surgeons have also discovered this tactic and use it, but the author has not found published information and has only disclosed it personally during the operative acts.

\section{TECHNIQUE}

At the end of a continuous suture, if the distal remnant is too short to be tied, an unpunched thread is passed through the last suture loop. It can be any available thread segment that is in operative field to be tied to support the knot tension and should have at least $10 \mathrm{~cm}$ long.
After passing through the last loop of the continuous suture, the auxiliary suture is folded over and pulled enough so that the continuous suture loop can be tied with the small distal remnant of the suture (Figure 1). Once the knot is completed, the auxiliary thread is removed or, if the continuous suture thread is extremely short, it may be included as part of the knot.

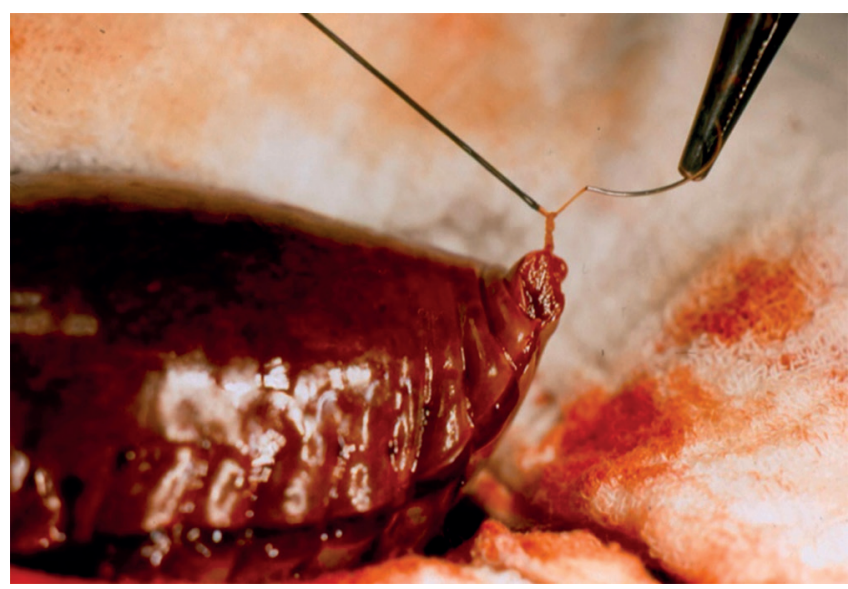

FIGURE 1 - Auxiliary thread for tying short suture in continuous suture: $2-0$ silk thread, pierced at the end of a continuous suture with 3-0 chrome catgut thread, for splenic capsule synthesis after subtotal splenectomy. It can be observed the knots that were made with the short catgut thread. Then the silk auxiliary thread is easily removed.

\section{DISCUSSION}

The role of the auxiliary thread resembles that of a catalyst, it enters the thread to be tied, facilitates giving the knot and at the end, it get out in same that have got in.

This technique has been used by the author for over 40 years, without prior publication and always with good results.

\section{REFERENCES}

1. Bernis-FilhoWO, Wouters F, Wouters AA, Bernis VM, Lopes LR, Andreollo NA. Comparative study of cotton, polyglactin and polyglecaprone sutures in intestinal anastomoses in dogs. Arq Bras Cir Dig. 2013 JanMar;26(1):18-26.

2. Bures C, Seika P, Denecke C, Pratschke J, Zorron R. Routine use of V-Lock ${ }^{\circledR}$ suture for bariatric anastomosis is safe: comparative results from consecutive case series. Arq Bras Cir Dig. 2019 Oct 21;32(3):e1452. doi: 10.1590/0102-672020190001e1452.

3. Petroianu A, Sabino KR, Alberti LR. Closure of large wound with rubber elasticcircularstrips-casereport.ArqBrasCirDig.2014Jan-Mar;27(1):86-7.

ORCID

Andy Petroianu: 0000-0002-8659-6866 